\title{
Characterization of Halorubrum sfaxense sp. nov., a New Halophilic Archaeon Isolated from the Solar Saltern of Sfax in Tunisia
}

\author{
Hana Trigui,, ${ }^{1,2}$ Salma Masmoudi, ${ }^{2}$ Céline Brochier-Armanet, ${ }^{1}$ \\ Sami Maalej, ${ }^{2}$ and Sam Dukan' \\ ${ }^{1}$ Laboratoire de Chimie Bactérienne, Aix Marseille Université, UPR 9043-CNRS, 31 Chemin Joseph Aiguier, \\ 13402 Marseille Cedex 20, France \\ ${ }^{2}$ Laboratoire de Microbiologie, Faculté des Sciences de Sfax, BP802, Sfax 3000, Tunisia
}

Correspondence should be addressed to Sam Dukan, sdukan@ifr88.cnrs-mrs.fr

Received 15 November 2010; Revised 2 March 2011; Accepted 31 March 2011

Academic Editor: Kaarina Sivonen

Copyright ( $) 2011$ Hana Trigui et al. This is an open access article distributed under the Creative Commons Attribution License, which permits unrestricted use, distribution, and reproduction in any medium, provided the original work is properly cited.

\begin{abstract}
An extremely halophilic archaeon, strain ETD6, was isolated from a marine solar saltern in Sfax, Tunisia. Analysis of the 16S rRNA gene sequence showed that the isolate was phylogenetically related to species of the genus Halorubrum among the family Halobacteriaceae, with a close relationship to Hrr. xinjiangense ( $99.77 \%$ of identity). However, value for DNA-DNA hybridization between strain ETD6 and Hrr. xinjiangense were about 24.5\%. The G+C content of the genomic DNA was $65.1 \mathrm{~mol} \%(\mathrm{~T}(\mathrm{~m}))$. Strain ETD6 grew in 15-35\% (w/v) NaCl. The temperature and $\mathrm{pH}$ ranges for growth were $20-55^{\circ} \mathrm{C}$ and 6-9, respectively. Optimal growth occurred at $25 \% \mathrm{NaCl}, 37^{\circ} \mathrm{C}$, and $\mathrm{pH}$ 7.4. The results of the DNA hybridization against Hrr. xinjiangense and physiological and biochemical tests allowed genotypic and phenotypic differentiation of strain ETD6 from other Hrr. species. Therefore, strain ETD6 represents a novel species of the genus Halorubrum, for which the name Hrr. sfaxense sp. nov. is proposed. The Genbank EMBL-EBI accession number is GU724599.
\end{abstract}

\section{Introduction}

Extremely halophilic archaea belong into a single euryarchaeotal order (Halobacteriales) that inhabits various hypersaline environments (3-5M) such as salt lakes, salt ponds, and marine salterns. Previous molecular ecology studies showed that archaeal halophiles dominate these ecosystems [1-3]. Halobacteriales contains a single family Halobacteriaceae with cultivated representatives in solar salterns. These organisms are known to promote crystal formation of halite [4]. Their cells act as seeds or nuclei to promote subsequent development of halite crystals [5]. The genus Halorubrum belongs to the family Halobacteriaceae, as first proposed by McGenity and Grant [6], and species of this genus are ubiquitous in hypersaline environments notably solar salterns. A recent study based on phylogenetic analysis of three ponds of the solar saltern of Sfax indicated that archaeal sequences were exclusively affiliated with the Halobacteriaceae: They were distributed among different genera of the Halobacteriaceae such as Haloquadratum, Halorubrum, and Halobacter [7]. Other studies assessing the diversity of halophilic Archaea in Korean salterns have shown that most sequences detected are grouped within the Halorubrum branch [8]. At the time of writing the genus Halorubrum [6, 9] contained 25 recognized species: Halorubrum aidingense [10], Halorubrum aquaticum [11], Halorubrum alkaliphilum [12], Halorubrum arcis [13], Halorubrum californiense [14], Halorubrum chaoviator [15], Halorubrum cibi [16], Halorubrum coriense [17, 18], Halorubrum distributum [19, 20], Halorubrum ejinorense [21], Halorubrum ezzemoulense [22], Halorubrum kocurii [23], Halorubrum lacusprofundi [24], Halorubrum lipolyticum [10], Halorubrum litoreum [25], Halorubrum luteum [26], Halorubrum orientale [27], Halorubrum saccharovorum [28], Halorubrum sodomense [29], Halorubrum tebenquichense [30], Halorubrum terrestre [31], Halorubrum tibetense [32], Halorubrum trapanicum [6], Halorubrum vacuolatum $[33,34]$, and Halorubrum xinjiangense [35]. 
In this paper, we describe a novel strain (ETD6) belonging to the genus Halorubrum on the basis of phenotypic and genotypic characteristics and of the polar lipid composition.

\section{Material and Methods}

2.1. Sample Collection. The strain ETD6 was isolated in March 2007 from a crystallizer pond (TS) (mean salinity is about $380 \mathrm{~g} \mathrm{~L}^{-1}$ ) of the solar saltern of Sfax, located in the central-eastern coast of Tunisia about $34-39^{\circ} \mathrm{N}$ and $10-42^{\circ} \mathrm{E}$ (Figure 1). The samples were taken a few centimeters below the water surface with a Van Dorn bottle and preserved in cold temperature until further processing in the laboratory (within 2 hours after collection).

2.2. Isolation Procedure. Isolations were performed on DSC97 medium containing the following ingredients : casamino acids $-7.5 \mathrm{~g}$, yeast extract $-10.0 \mathrm{~g}$, trisodium citrate $-3.0 \mathrm{~g}$, $\mathrm{KCl}-2.0 \mathrm{~g}, \mathrm{MgSO}_{4} \cdot 7 \mathrm{H}_{2} \mathrm{O}-20.0 \mathrm{~g}, \mathrm{FeCl}_{2} \cdot 4 \mathrm{H}_{2} \mathrm{O}-0.036 \mathrm{~g}$, $\mathrm{NaCl}-200 \mathrm{~g}$, agar- $15 \mathrm{~g}$, and distilled water- $1000 \mathrm{~mL}, \mathrm{pH}$ 7.4. Dilutions were spread on DSC-97 agar plates. After incubating at $37^{\circ} \mathrm{C}$ for $15-20$ days, one isolate representative of each dominant morphotype (based on gross morphology: pigmentation, size, and margin of colony) was selected for isolation. Different colonies were purified by at least four rounds of streaking on fresh agar plates until a pure colony was obtained. The isolates were maintained as a glycerol suspension $(40 \%, \mathrm{w} / \mathrm{v})$ at $-80^{\circ} \mathrm{C}$.

2.3. Optimum Growth Conditions. The $\mathrm{pH}$, temperature, and $\mathrm{NaCl}$ ranges for growth were determined in DSC-97 growth medium. Strain ETD6 grew over a temperature, range of $\left(20-55^{\circ} \mathrm{C}\right)$ as determined by using a temperature gradient incubator and over a $\mathrm{pH}$ range of 6.0-9.0 as determined with various $\mathrm{pH}$ buffers. Routine cultivation was performed at $37^{\circ} \mathrm{C}$ and $\mathrm{pH}$ 7.4. The requirements for $\mathrm{NaCl}$ for growth were determined in media with $15-35 \%(\mathrm{w} / \mathrm{v}) \mathrm{NaCl}$.

2.4. Morphological Observation. Cell motility and morphology were examined using an automated microscope (Nikon TE2000-E-PFS, Nikon, France) equipped with a CoolSNAP HQ 2 camera (Roper Scientific, Roper Scientific SARL, France) and a 100x/1.4 DLL objective. Gram staining was carried out as described by Dussault [37].

2.5. Phylogenetic Analysis. Cell suspension from each isolate was prepared in $100 \mu \mathrm{L}$ of DNAase RNAase free water and frozen at $-80^{\circ} \mathrm{C}$ for $10 \mathrm{~min}$ then heated at $98^{\circ} \mathrm{C}$ for $10 \mathrm{~min}$ to release the DNA. The sample obtained after the thermic shock was used as a template for PCR amplification of 16S rDNA with specific archaeal 16S rRNA gene primers [38], 21f ( $5^{\prime}$-TTCCGGTTGATCCYGCCGGA-3' $)$, and 958r $\left(5^{\prime}\right.$-YCCGGCGTTGAMTCCAATT- $\left.{ }^{\prime}\right)$. Each amplification reaction mixture $(50 \mu \mathrm{L})$ contained PCR buffer $(1 \mathrm{x}), 0.2 \mathrm{mM}$ of each dNTP, $0.1 \mu \mathrm{M}$ of each primer, $2 \mu \mathrm{L}$ of template DNA, and $1 \mathrm{U}$ of high-fidelity expand DNA polymerase (Roche). After initial denaturation $\left(94^{\circ} \mathrm{C}\right.$ for $\left.5 \mathrm{~min}\right), 30$ cycles of $94^{\circ} \mathrm{C}$ for $30 \mathrm{~s}, 55^{\circ} \mathrm{C}$ for $30 \mathrm{~s}$, and $72^{\circ} \mathrm{C}$ for $1 \mathrm{~min}$ were performed, followed by a final extension $\left(10 \mathrm{~min}, 72^{\circ} \mathrm{C}\right)$. The PCR products were purified, ligated to pGEM T-easy vector (Promega), and transformed into E. coli DH5 $\alpha$ cells. Single colonies containing inserts were selected at random, and the inserts were amplified from cells using the primers Sp6 (5'-ATTTAGGTGACACTATAGAATAC-3') and T7 (5'GTAATACGACTCACTATAGGGC- $3^{\prime}$ ). Successful transformants were maintained as $40 \%$ glycerol stocks. The plasmids extracted were sent to Genome express for sequencing the 16S rRNA gene of each strain. The sequences were registered in the GenBank Data Library under the accession number GU724599. Homologues of ETD6 sequence were retrieved from the $n r$ database at the NCBI using Blastn (http://blast.ncbi.nlm.nih.gov/) [39] and aligned with ClustalW (Larkin Clustal W and Clustal X version 2.0, 2007). The maximum likelihood phylogenetic tree was inferred using TreeFinder [49] with a Jukes and Cantor model on the 1363 unambiguously aligned positions. The statistical robustness of inferred branches was estimated by the non parametric bootstrap procedure implemented in TreeFinder (100 replicates of the original alignment).

2.6. Biophysical and Biochemical Characteristics. The physiological characterization of a novel halophilic archaeon was guided by Oren et al., [40] with the proposed minimal standards for description of new taxa in the order Halobacteriales.

The phenotypic tests for nitrate reduction, indole formation, and hydrolysis of casein, starch, and urea, were performed as described by Gerhardt et al. [41]. The assimilation of sugars as single carbon sources was tested with modified Bushnell-Haas medium [42] supplemented with $0.05 \%$ (w/v) yeast extract, 2\% (w/v) $\mathrm{MgCl}_{2} 0.01 \%$ (w/v) sugar (glycerol, D-glucose, sucrose, galactose, xylose, mannose, arabinose, or maltose), and $25 \% \mathrm{NaCl}$. Production of acid from sugars and other compounds was determined as described by Arahal et al., [43].

Antibiotic sensitivity tests were performed by spreading bacterial suspensions on culture plates and applying discs impregnated with the following concentrations (in $\mu \mathrm{g} / \mathrm{disc}$ unless indicated otherwise): ampicillin (10), bacitracin (10 U), chloramphenicol (30), erythromycin (15), gentamicin (10), novobiocin (30), penicillin $\mathrm{G}(10 \mathrm{U})$, rifampicin (30), streptomycin (10), sulfamethoxazole (25), and tetracycline (30). Oxidase activity was determined by oxidation of tetramethyl-p-phenylenediamine, and catalase activity was determined spectrophotometrically at $240 \mathrm{~nm}$ with $20 \mathrm{mM}$ $\mathrm{H}_{2} \mathrm{O}_{2}$ [44].

2.7. Cellular Fatty Acid Analysis. Polar lipid analysis was carried out by the identification service of the DSMZ and Dr. B. J. Tindall, DSMZ, Braunschweig, Germany, using cell material grown under identical conditions of optimum growth.

2.8. Determination of $G+C$ Content. The $\mathrm{G}+\mathrm{C}$ content of DNA was determined at DSMZ-Deutsche Sammlung von Mikroorganismen und Zellkulturen GmbH, Braunschweig, 


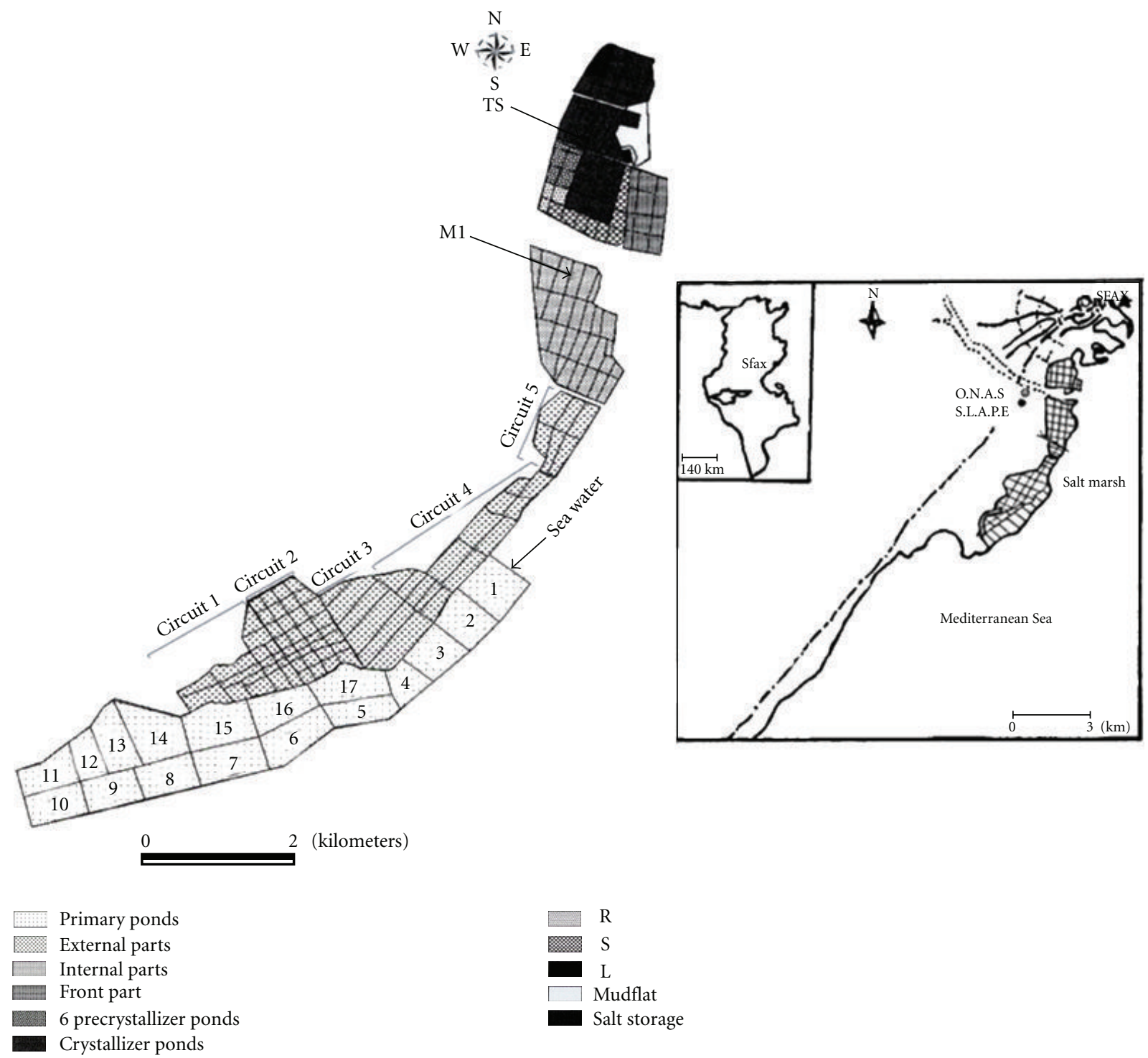

FIGURE 1: Map of the location of the sampling pond (TS) of the Sfax Solar Saltern in Tunisia [36].

Germany. The DNA was isolated and purified by chromatography on hydroxyapatite, and the $\mathrm{G}+\mathrm{C}$ content was determined by high-performance liquid chromatography (HPLC) as described by Mesbah et al. [45]. Calibration of the method was performed using nonmethylated lambda-DNA (Sigma) possessing a known $\mathrm{G}+\mathrm{C}$ content of $49.9 \mathrm{~mol} \%$ [45], as well as three genomic DNAs for which complete genome sequences have been published (Bacillus subtilis DSM 402 ( $\mathrm{G}+\mathrm{C}$ content of $43.5 \mathrm{~mol} \%)$, Xanthomonas campestris pv. campestris DSM 3586T (G+C content of $65.1 \mathrm{~mol} \%)$, and Streptomyces violaceoruber DSM 40783 (G+C content of $72.1 \mathrm{~mol} \%)$ ).

2.9. DNA-DNA Hybridization. Analysis was performed by the identification service of the DSMZ. DNA was isolated using French press cell (thermo Spectronic) and purified by chromatography on hydroxypatite as described by Cashion et al. [46]. DNA-DNA hybridization was carried out as described by Deley et al. [47] under consideration of the modifications described by Huss et al., [48] using a model Cary 100 Bio UV/VIS-spectrophotometer equipped with a Peltier Thermostatted $6 \times 6$ multicell changer and a temperature controller with in situ temperature probe (Varian).

\section{Results and Discussion}

At the time of sampling, the water of the pond had a temperature of $25^{\circ} \mathrm{C}$, a pH of 7.55 , a salinity of $37.76 \%(\mathrm{w} / \mathrm{v})$, and the conductivity was $680 \mathrm{mS} \mathrm{cm}^{-1}$. Water analyses and cell counts are presented in Table 1 . The total cell count was $4.1 \times$ $10^{7}$ cells $\mathrm{mL}^{-1}$ in TS. This measurement in March 2007 was similar to those reported for other marine solar salterns [50, 51]. 


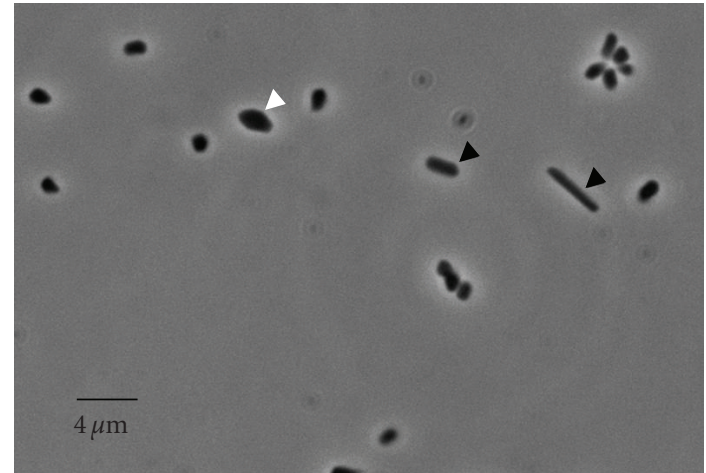

FIgURE 2: Phase contrast photomicrograph of strain ETD6. Strain grown in the liquid medium DSC-97 under optimal conditions until $\mathrm{OD}_{00 \mathrm{~nm}}=1.0$. Black arrows show rod-shaped cells, white arrows show cocci shaped-cell (30 hours of growth).

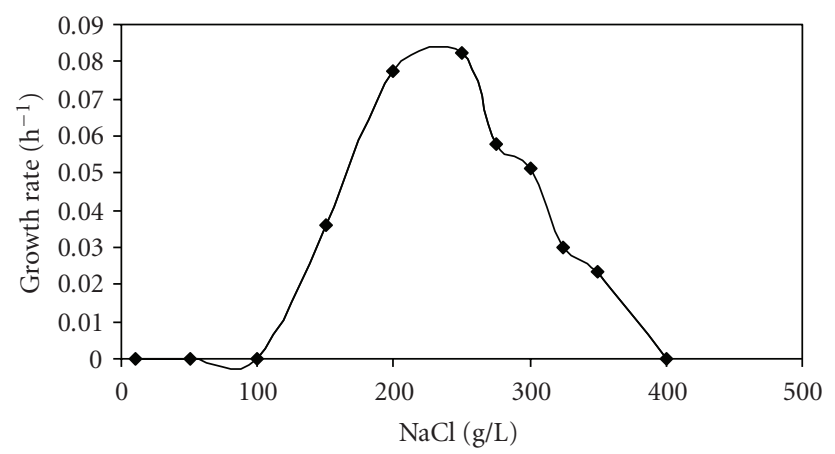

Figure 3: Effect of $\mathrm{NaCl}$ concentration on growth rate of strain ETD6 cultivated in the medium DSC-97. Cultures were incubated at $37^{\circ} \mathrm{C}$. Experiments were repeated at least three times, and the standard deviation was always below $10 \%$.

TABle 1: Physicochemical characteristics of TS pond on March 2007.

\begin{tabular}{|c|c|}
\hline Ponds & TS \\
\hline \multicolumn{2}{|l|}{ Physical parameters } \\
\hline Salinity (\%) & 37.76 \\
\hline Temperature $\left({ }^{\circ} \mathrm{C}\right)$ & 25 \\
\hline $\mathrm{pH}$ & 7.55 \\
\hline $\mathrm{EC}\left(\mathrm{mS} \mathrm{cm}^{-1}\right)$ & 680.00 \\
\hline \multicolumn{2}{|l|}{ Major actions and anions $\left(\mathrm{gl}^{-1}\right)$} \\
\hline $\mathrm{Na}^{+}$ & 87.5 \\
\hline $\mathrm{Ca}^{+}$ & 0.043 \\
\hline $\mathrm{Mg}^{2+}$ & 0.29 \\
\hline $\mathrm{Cl}^{-}$ & 261.09 \\
\hline $\mathrm{K}^{+}$ & 8.5 \\
\hline $\mathrm{SO}_{4}^{-2}$ & 43.2 \\
\hline Total cell count $\left(10^{7}\right.$ cells $\left.\mathrm{mL}^{-1}\right)$ & 4.1 \\
\hline
\end{tabular}

Cells of strain ETD6 were Gram-negative, nonmotile, and showed pleomorphic shape (rods, rod in golfment, and cocci) occurring individually, in pairs, or irregular clusters (Figure 2). Colonies on agar medium after incubation at $37^{\circ} \mathrm{C}$ for 15 to 20 days were red-orange, entire, translucent, fat, smooth, slightly raised, and $0.5-1 \mathrm{~mm}$ in diameter.

To analyze the phylogenetic position, the $16 \mathrm{~S}$ rRNA gene sequence of strain ETD6 was determined. The best blast hits were observed with sequences from the Halobacteriales order and more precisely with representatives of the Halorubrum genus, suggesting that ETD6 may be a new representative of this group. Among sequences from cultivated organisms, the sequence Hrr. xinjiangense (AY994197) displayed the highest similarity (99.77\%) with ETD6, suggesting that they may be closely related (Figure 4 ). The multiple alignment revealed that these two sequences harbored only two specific differences (i.e., that are not present in other $16 \mathrm{~S}$ rRNA sequences): an insertion is observed in the ETD6 sequence at position 346 of the alignment, and a second insertion is observed in the sequence from Hrr. xinjiangense at position 885 of the alignment. The close relationship between the 16S rRNA sequences from ETD6 and Hrr. xinjiangense was confirmed by the phylogenetic analysis (Figure 4). These two sequences form a monophyletic cluster in this tree. The high similarity observed between $16 \mathrm{~S}$ rRNA sequences from ETD6 and Hrr. xinjiangense suggests that these strains are two representatives of the same species.

DNA hybridization is acknowledged as the superior method for the elucidation of relationships between closely related taxa, such as strains and species [52]. The level of DNA-DNA relatedness between strain ETD6 and Hrr. xinjianrense was about $24.5 \%$. This level was less than $70 \%$, justifying the classification of ETD6 in a distinct species within the genus Halorubrum [52]. The low level of DNADNA hybridization was at odds with the high percentage of identity observed between $16 \mathrm{~S}$ rRNA sequences from these two strains. This suggested that measures of $16 \mathrm{~S}$ rRNA divergence are not a good tool to identify new species in this genus. In fact, Hrr. sp. are excellent models for field and laboratory studies with close $16 \mathrm{~S}$ rRNA genes (99\% of identity) and very diverse physiological features and dynamic genomes [53].

The $\mathrm{G}+\mathrm{C}$ content of the DNA of strain ETD6 as determined by HPLC was $65.1 \mathrm{~T}(\mathrm{~m}) \mathrm{mol} \%$. The genomic DNA $\mathrm{G}+\mathrm{C}$ content in the valid species names of the genus Halorubrum is in the range of $60.2 \sim 71.2 \mathrm{~mol} \%[9,54]$.

Polar lipid analysis was carried out by the identification service of the DSMZ and Dr. B. J. Tindall, DSMZ, Braunschweig, Germany. 2D TLC of extracts of strain (ETD6) revealed that this organism contained phosphatidylglycerol, methyl-phosphatidylglycerophosphate, phosphatidylglycerosulphate, phospholipids, unknown glycolipid, and two unknown lipids.

The isolate was an extreme halophilic archaeon growing in high concentrations of $\mathrm{NaCl}$ ranging from 15 to $35 \%(\mathrm{w} / \mathrm{v})$ $\mathrm{NaCl}$ with an optimum at 25\% (Figure 3).

The strain ETD6 is able to reduce nitrate to nitrite, suggesting that it may be involved in the global nitrogen cycle within the solar saltern. The isolate was catalase-positive and oxidase-negative, and was negative for indole formation, positive for the assimilation of glucose, xylose, mannose, arabinose, and maltose, but not sucrose, galactose, or glycerol. ETD6 is an amylase-positive which is not the case for 

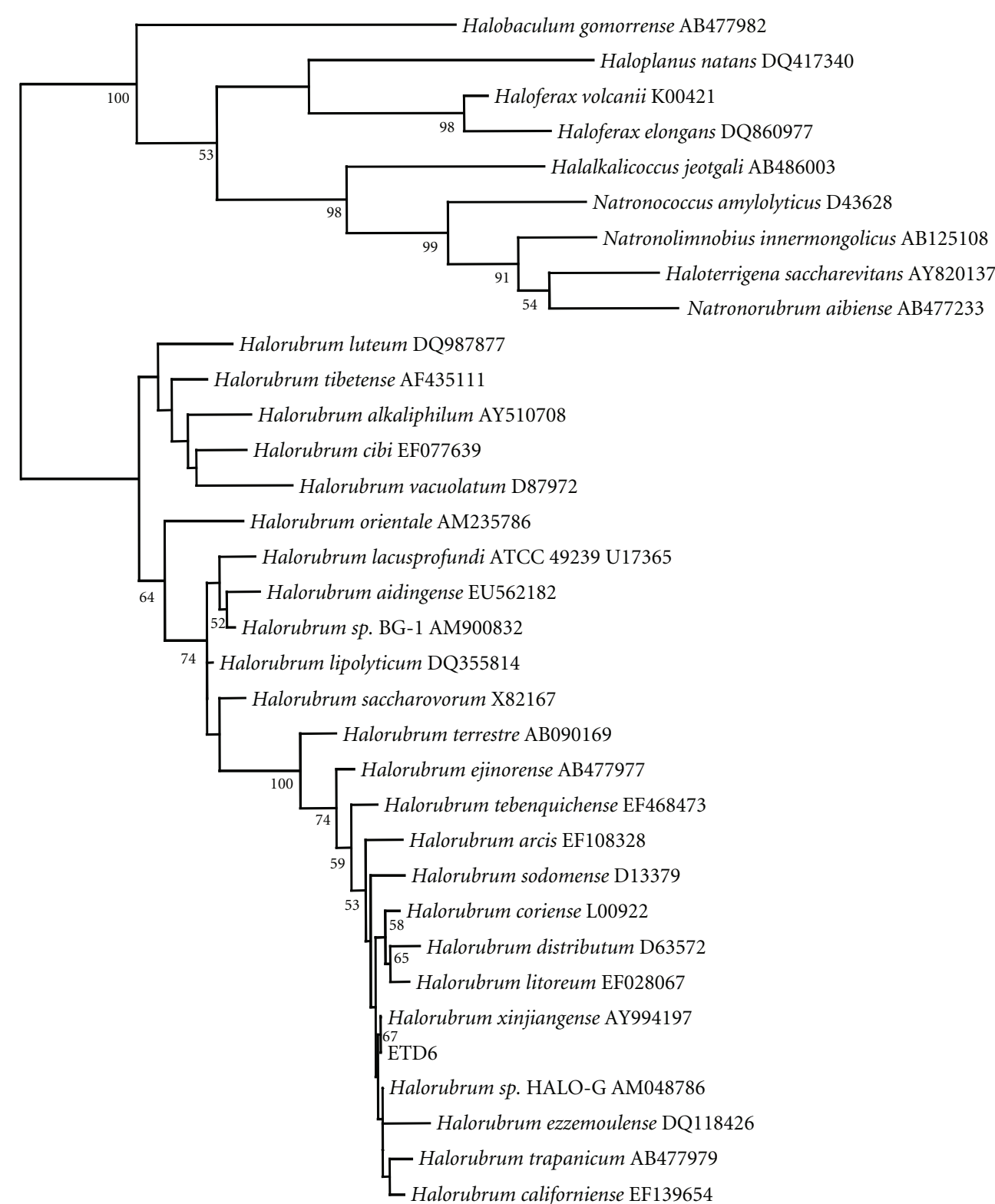

0.1

EDT6_10-bb.tre

(34 sequences, 1363 positions)

FIGURE 4: Maximum likelihood phylogenetic tree of 66 halobacteriales sequences showing the position of strain ETD6 among the species of genus Halorubrum and other genera of extremely halophilic archaea. The tree was reconstructed using Treefinder [49] with a Jukes and Cantor model. Values at nodes represent bootstrap values computed with Treefinder (100 replicates of the original dataset). The scale bar represents the average number of substitutions by site. Halorubrum sp. BG-1 AM900832 correspond to Halorubrum kocurii; Halorubrum sp. HALO-G AM048786 correspond to Halorubrum chaoviator.

the other Halorubrum species isolated up to date. As the use of amylase from halophilic microorganisms in industrial processes have the advantage of the enzymes having optimal activities at high salt concentrations $[55,56]$, studies on ETD6 should be reinvestigated as it constitutes a source of halo-stable enzymes that offer potential applications in various industries.
As shown in Table 2, the new isolate (ETD6) could be readily differentiated from Hrr. xinjiangense on the basis of several characteristics.

Because of significant phenotypic, phylogenetic, and genetic differences between this strain and all the validly published members of the family Halorubrum, we propose that it may be classified as a novel species: Halorubrum. sp. nov. 
TABle 2: Differential characteristics of ETD6 and Halorubrum xinjiagense. Strains: 1, strain ETD6 (tested in this study); 2, Halorubrum xinjiangenese AS $1.3527^{\mathrm{T}}$ [35]. +, Positive; -, negative; ND, no data available.

\begin{tabular}{|c|c|c|}
\hline & 1 & 2 \\
\hline \multicolumn{3}{|l|}{ Characteristics: } \\
\hline Morphology & Pleomorphic & Rods \\
\hline Motility & + & + \\
\hline Gram stain reaction & - & - \\
\hline $\mathrm{NaCl}$ range $(\%)$ & $15-35$ & $11.8-30.1$ \\
\hline $\mathrm{NaCl}$ optimum (\%) & 25 & $17.8-19.7$ \\
\hline Temperature range $\left({ }^{\circ} \mathrm{C}\right)$ & $20-55$ & $10-54$ \\
\hline Temperature optimum $\left({ }^{\circ} \mathrm{C}\right)$ & 37 & 40 \\
\hline $\mathrm{pH}$ range & $6.0-9.0$ & $6.0-10$ \\
\hline $\mathrm{pH}$ optimum & 7.4 & $7-7.5$ \\
\hline Doubling time $(\mathrm{h})$ & 8.4 & ND \\
\hline $\mathrm{G}+\mathrm{C}$ content $(\%)$ & 65.1 & 68 \\
\hline Hydrolysis of starch & + & - \\
\hline Hydrolysis of casein & - & ND \\
\hline Urease & - & ND \\
\hline \multicolumn{3}{|l|}{ Use of substrates: } \\
\hline Starch & + & ND \\
\hline Glycerol & - & ND \\
\hline Galactose & - & - \\
\hline Sucrose & - & + \\
\hline Xylose & + & ND \\
\hline Mannose & + & ND \\
\hline Arabinose & + & ND \\
\hline Indole & - & - \\
\hline Nitrate reduction & + & - \\
\hline Oxidase & - & + \\
\hline ONPG & + & ND \\
\hline
\end{tabular}

The above phenotypic, genotypic, chemotaxonomic, and phylogenetic data indicate that strain ETD6 may represent a novel species within the genus Halorubrum for which the name Halorubrum sfaxense sp. nov. is proposed.

\section{Description of Halorubrum sfaxense sp. nov}

Halorubrum sfaxense (sfa. xi. en'se. N.L. neut. adj. sfax pertaining to Sfax, where the strain was isolated from a solar saltern).

Cells are Gram-negative, pleomorphic shaped $(2-5 \times$ $0.86 \mu \mathrm{m}$ ), and motile. Colonies are small, round, $0.5-1 \mathrm{~mm}$ in diameter, red orange, smooth, and slightly raised. Growth occurs optimally at $25 \% \mathrm{NaCl}$ and over the range $15-35 \%$ $\mathrm{NaCl}$ (Extreme halophile). The $\mathrm{pH}$ range for growth is 6-9, with optimum growth at $\mathrm{pH}$ 7.4. The temperature range is $20-55^{\circ} \mathrm{C}$; optimal temperature for growth is $37^{\circ} \mathrm{C}$. Magnesium is not required for growth. They are strictly aerobic and positive for catalase while Kovac's oxidase negative. Starch is hydrolysed while casein is not hydrolysed. $\mathrm{H}_{2} \mathrm{~S}$ is not produced. Nitrate is reduced to nitrite. Indole is not produced. D-Glucose, maltose, xylose, arabinose, and mannose are used as single carbon sources with acid production. No growth or acid production is observed on sucrose, galactose, and glycerol. They are sensitive to bacitracin, novobiocin, streptomycin, sulfamethoxazole, gentamicin, and tetracycline and resistant to ampicillin, chloramphenicol, rifampicin, erythromycin, and penicillin G. The polar lipids are PG, PGP-Me, PGS, single glycolipid GL, phospholipids PL1-PL2, and lipids L1-L2.

\section{Acknowledgments}

The authors are grateful to acknowledge the COTUSAL staff (Tunisia) for allowing access to the solar saltern and sampling and to $\mathrm{CMCU}$ and AUF organisms which financed this project. C. B. Armant is supported by an Action Thématique et Incitative sur Programme (ATIP) of the French Centre National de la Recherche Scientifique (CNRS).

\section{References}

[1] C. D. Litchfield and P. M. Gillevet, "Microbial diversity and complexity in hypersaline environments: a preliminary assessment," Journal of Industrial Microbiology and Biotechnology, vol. 28, no. 1, pp. 48-55, 2002.

[2] T. Ochsenreiter, F. Pfeifer, and C. Schleper, "Diversity of Archaea in hypersaline environments characterized by molecular-phylogenetic and cultivation studies," Extremophiles, vol. 6, no. 4, pp. 267-274, 2002.

[3] L. Ovreas, F. L. Daae, V. Torsvik et al., "Characterization of microbial diversity in hypersaline environments by melting profiles and reassociation kinetics in combination with terminal restriction fragment length polymorphism (T-RFLP)," Microbial Ecology, vol. 46, no. 3, pp. 291-301, 2003.

[4] C. A. Lopez and J. L. Ochoa, "The biological significance of Halobacteria on nucleation and sodium chloride crystal growth," in Absorption and Its Applications in Industry and Environmental Protection, Studies in Surface Science and Catalysis, A. Dubrowski, Ed., vol. 120, Elsevier, Amsterdam, The Netherlands, 1998.

[5] C. F. Norton and W. D. Grant, "Survival of Halobacteria within fluid inclusions in salt crystals," Journal of General Microbiology, vol. 134, pp. 1365-1373, 1988.

[6] T. J. McGenity and W. D. Grant, "Transfer of Halobacterium saccharovorum, Halobacterium sodomense, Halobacterium trapanicum NRC 34021 and Halobacterium lacusprofundi to the genus Halorubrum gen . nov., as Halorubrum saccharovorum comb . nov., Halorubrum sodomense comb. nov., Halorubrum trapanicum comb. nov., and Halorubrum lacusprofundi comb. nov," Systematic and Applied Microbiology, vol. 18, no. 2, pp. 237-243, 1995.

[7] H. Baati, S. Guermazi, and R. Amdouni, "Prokaryotic diversity of a Tunisian multipond solar saltern," Extremophiles, vol. 12, no. 4, pp. 505-518, 2008.

[8] S. J. Park, C. H. Kang, and S. K. Rhee, "Characterization of the microbial diversity in a Korean solar saltern by $16 \mathrm{~S}$ rRNA gene analysis," Journal of Microbiology and Biotechnology, vol. 16, no. 10, pp. 1640-1645, 2006.

[9] T. J. McGenity and W. D. Grant, "Genus VII. Halorubrum," in Bergey's Manual of Systematic Bacteriology, D. R. Boone, R. W. Castenholz, and G. M. Garrity, Eds., vol. 1, Springer, NewYork, NY, USA, 2nd edition, 2001. 
[10] H. L. Cui, D. Tohty, and P. J. Zhou, "Halorubrum lipolyticum sp. nov. and Halorubrum aidingense sp. nov., isolated from two salt lakes in Xin-Jiang, China," International Journal of Systematic and Evolutionary Microbiology, vol. 56, no. 7, pp. 1631$1634,2006$.

[11] M. C. Gutiérrez, A. M. Castillo, P. Corral et al., "Halorubrum aquaticum sp. nov., an archaeon isolated from hypersaline lakes," International Journal of Systematic and Evolutionary Microbiology, vol. 61, 2011.

[12] J. Feng, P. Zhou, Y. G. Zhou et al., "Halorubrum alkaliphilum sp. nov., a novel haloalkaliphile isolated from a soda lake in Xinjiang, China," International Journal of Systematic and Evolutionary Microbiology, vol. 55, no. 1, pp. 149-152, 2005.

[13] X. W. Xu, Y. H. Wu, H. B. Zhang et al., "Halorubrum arcis sp. nov., an extremely halophilic archaeon isolated from a saline lake on the Qinghai-Tibet Plateau, China," International Journal of Systematic and Evolutionary Microbiology, vol. 57, no. 5, pp. 1069-1072, 2007.

[14] P. T. Pesenti, M. Sikaroodi, P. M. Gillevet et al., "Halorubrum californiense sp. nov., an extreme archaeal halophile isolated from a crystallizer pond at a solar salt plant in California, USA," International Journal of Systematic and Evolutionary Microbiology, vol. 58, no. 12, pp. 2710-2715, 2008.

[15] R. L. Mancinelli, R. Landheim, C. Sánchez-Porro et al., "Halorubrum chaoviator sp. nov., a haloarchaeon isolated from sea salt in Baja California, Mexico, Western Australia and Naxos, Greece," International Journal of Systematic and Evolutionary Microbiology, vol. 59, no. 8, pp. 1908-1913, 2009.

[16] S. W. Roh and J. W. Bae, "Halorubrum cibi sp. nov., an extremely halophilic archaeon from salt-fermented seafood," Journal of Microbiology, vol. 47, no. 2, pp. 162-166, 2009.

[17] M. Kamekura and M. L. Dyall-Smith, "Taxonomy of the family Halobacteriaceae and the description of two new genera Halorubrobacterium and Natrialba," Journal of General and Applied Microbiology, vol. 41, no. 4, pp. 333-350, 1995.

[18] A. Oren and A. Ventosa, "A proposal for the transfer of Halorubrobacterium distributum and Halorubrobacterium coriense to the genus Halorubrum as Halorubrum distributum comb. nov. and Halorubrum coriense comb. nov., respectively," International Journal of Systematic Bacteriology, vol. 46, no. 4, p. 1180, 1996.

[19] I. S. Zvyagintseva and A. L. Tarasov, "Extreme halophilic bacteria from saline soils," Microbiology (English translation of Mikrobiologiya), vol. 56, pp. 839-844, 1987 (Russian).

[20] I. S. Zvyagintseva, E. B. Kudryashova, E. S. Bulygina et al., "Proposal of a new type strain of Halobacterium distributum," Microbiology (English translation of Mikrobiologiya), vol. 65, no. 3, pp. 352-354, 1996.

[21] A. M. Castillo, M. C. Gutiérrez, M. Kamekura et al., "Halorubrum ejinorense sp. nov., isolated from Lake Ejinor, Inner Mongolia, China," International Journal of Systematic and Evolutionary Microbiology, vol. 57, no. 11, pp. 2538-2542, 2007.

[22] K. Kharroub, T. Quesada, R. Ferrer et al., "Halorubrum ezzemmoulense sp. nov., a halophilic archaeon isolated from Ezzemoul sabkha, Algeria," International Journal of Systematic and Evolutionary Microbiology, vol. 56, no. 7, pp. 1583-1588, 2006.

[23] M. C. Gutiérrez, A. M. Castillo, E. Pagaling et al., "Halorubrum kocurii nov., an archaeon isolated from a saline lake," International Journal of Systematic and Evolutionary Microbiology, vol. 58, no. 9, pp. 2031-2035, 2008.

[24] P. D. Franzmann, E. Stackebrandt, K. Sanderson et al., "Halobacterium lacusprofundi nov., a halophilic bacterium isolated from Deep Lake, Antarctica," Systematic and Applied Microbiology, vol. 11, pp. 20-27, 1988.

[25] H. L. Cui, Z. Y. Lin, Y. Dong et al., "Halorubrum litoreum sp. nov., an extremely halophilic archaeon from a solar saltern," International Journal of Systematic and Evolutionary Microbiology, vol. 57, no. 10, pp. 2204-2206, 2007.

[26] L. Hu, H. Pan, Y. Xue et al., "Halorubrum luteum sp. nov., isolated from Lake Chagannor, Inner Mongolia, China," International Journal of Systematic and Evolutionary Microbiology, vol. 58, no. 7, pp. 1705-1708, 2008.

[27] A. M. Castillo, M. C. Gutiérrez, M. Kamekura et al., "Halorubrumorientale nov., a halophilic archaeon isolated from Lake Ejinor, Inner Mongolia, China," International Journal of Systematic and Evolutionary Microbiology, vol. 56, no. 11, pp. 2559-2563, 2006.

[28] G. A. Tomlinson and L. I. Hochstein, "Halobacterium saccharovorum sp. nov., a carbohydrate metabolizing, extremely halophilic bacterium," Canadian Journal of Microbiology, vol. 22, no. 4, pp. 587-591, 1976.

[29] A. Oren, "Halobacterium sodomense sp. nov., a dead sea halobacterium with an extremely high magnesium requirement," International Journal of Systematic Bacteriology, vol. 33, no. 2, pp. 381-386, 1983.

[30] C. Lizama, M. Monteoliva-Sánchez, A. Suárez-Garciá et al., "Halorubrum tebenquichense sp. nov., a novel halophilic archaeon isolated from the Atacama Saltern, Chile," International Journal of Systematic and Evolutionary Microbiology, vol. 52, no. 1, pp. 149-155, 2002.

[31] A. Ventosa, M. C. Gutiérrez, M. Kamekura et al., "Taxonomic study of Halorubrum distributum proposal of Halorubrum terrestre sp. nov," International Journal of Systematic and Evolutionary Microbiology, vol. 54, no. 2, pp. 389-392, 2004.

[32] H. Fan, Y. Xue, Y. Ma et al., "Halorubrum tibetense sp. nov., a novel haloalkaliphilic archaeon from Lake Zabuye in Tibet, China," International Journal of Systematic and Evolutionary Microbiology, vol. 54, no. 4, pp. 1213-1216, 2004.

[33] W. E. Mwatha and W. D. Grant, "Natronobacterium vacuolata sp. nov., a haloalkaliphilic archaeon isolated from Lake Magadi, Kenya," International Journal of Systematic Bacteriology, vol. 43, no. 3, pp. 401-404, 1993.

[34] M. Kamekura, M. L. Dyall-Smith, V. Upasani et al., "Diversity of alkaliphilic halobacteria: proposals for transfer of Natronobacterium vacuolatum, Natronobacterium magadii, and Natronobacterium pharaonis to Halorubrum, Natrialba, and Natronomonas gen. nov., respectively, as Halorubrum vacuolatum comb. nov., Natrialba magadii comb. nov., and $\mathrm{Na}$ tronomonas pharaonis nov., respectively," International Journal of Systematic Bacteriology, vol. 47, no. 3, pp. 853-857, 1997.

[35] J. Feng, P. J. Zhou, and S. J. Liu, "Halorubrum xinjiangense sp. nov., a novel halophile isolated from saline lakes in China," International Journal of Systematic and Evolutionary Microbiology, vol. 54, no. 5, pp. 1789-1791, 2004.

[36] R. Amdouni, Etude géochimique des saumures libres, des sédiments et des sels dans la saline de Sfax (Tunisie),, Ph.D. thesis, Thése de l' Université, Paris, France, 1990.

[37] H. P. Dussault, "An improved technique for staining red halophilic bacteria," Journal of Bacteriology, vol. 70, no. 4, pp. 484-485, 1955.

[38] E. F. DeLong, "Archaea in coastal marine environments," Proceedings of the National Academy of Sciences of the United States of America, vol. 89, no. 12, pp. 5685-5689, 1992.

[39] S. F. Altschul, W. Gish, W. Miller et al., "Basic local alignment search tool," Journal of Molecular Biology, vol. 215, no. 3, pp. 403-410, 1990. 
[40] A. Oren, A. Ventosa, and W. D. Grant, "Proposed minimal standards for description of new taxa in the order Halobacteriales," International Journal of Systematic Bacteriology, vol. 47, no. 1, pp. 233-238, 1997.

[41] P. Gerhardt, R. G. E. Murray, W. A. Wood et al., Eds., Methods for General and Molecular Bacteriology, American Society for Microbiology, Washington, DC, USA, 1994.

[42] E. J. Brown and J. F. Braddock, "Sheen Screen: a miniaturized most-probable-number method for enumeration of oildegrading microorganisms," Applied Environmental of Microbiology, vol. 56, no. 12, pp. 3895-3896, 1990.

[43] D. R. Arahal, F. E. Dewhirst, B. J. Paster et al., "Phylogenetic analyses of some extremely halophilic archaea isolated from dead sea water, determined on the basis of their 16S rRNA sequences," Applied and Environmental Microbiology, vol. 62, no. 10, pp. 3779-3786, 1996.

[44] R. F. Beers Jr. and I. W. Sizer, "A spectrophotometric method for measuring the breakdown of hydrogen peroxide by catalase," The Journal of Biological Chemistry, vol. 195, no. 1, pp. 133-140, 1952.

[45] M. Mesbah, U. Premchandran, and W. B. Whitman, "Precise measurement of the $\mathrm{G}+\mathrm{C}$ content of deoxyribonucleic acid by high performance liquid chromatography," International Journal of Systematic Bacteriology, vol. 39, no. 2, pp. 159-167, 1989.

[46] P. Cashion, M. A. Holder Franklin, J. McCully et al., "A rapid method for the base ratio determination of bacterial DNA," Analytical Biochemistry, vol. 81, no. 2, pp. 461-466, 1977.

[47] J. Deley, H. Cattoir, and A. Reynaertas, "The quantitative measurements of DNA hybridization from renaturation rates," European Journal of Biochemistry, vol. 12, pp. 133-142, 1970.

[48] V. A. R. Huss, H. Festl, and K. H. Schleifer, "Studies on the spectrophotometric determination of DNA hybridization from renaturation rates," Systematic and Applied Microbiology, vol. 4, no. 2, pp. 184-192, 1983.

[49] G. Jobb, A. Von Haeseler, and K. Strimmer, “TREEFINDER: a powerful graphical analysis environment for molecular phylogenetics," BMC Evolutionary Biology, vol. 4, p. 18, 2004.

[50] M. B. Mutlu, M. Martínez-García, F. Santos et al., "Prokaryotic diversity in Tuz Lake, a hypersaline environment in Inland Turkey," FEMS Microbiology Ecology, vol. 65, no. 3, pp. 474483, 2008.

[51] A. Oren, "Thymidine incorporation in saltern ponds of different salinities: estimation of in situ growth rates of halophilic archaeobacteria and eubacteria," Microbial Ecology, vol. 19, no. 1, pp. 43-51, 1990.

[52] E. Stackebrandt and B. M. Goebel, "A place for DNA-DNA reassociation and 16S rRNA sequence analysis in the present species definition in bacteriology," International Journal of Systematic Bacteriology, vol. 44, no. 4, pp. 846-849, 1994.

[53] R. T. Papke, O. Zhaxybayeva, E. J. Feil et al., "Searching for species in haloarchaea," Proceedings of the National Academy of Sciences of the United States of America, vol. 104, no. 35, pp. 14092-14097, 2007.

[54] A. Oren, D. R. Arahal, and A. Ventosa, "Emended descriptions of genera of the family Halobacteriaceae," International Journal of Systematic and Evolutionary Microbiology, vol. 59, no. 3, pp. 637-642, 2009.

[55] M. Kamekura, "Production and function of enzymes of eubacterial halophiles," FEMS Microbiology Reviews, vol. 39, no. 1-2, pp. 145-150, 1986.

[56] A. Ventosa and J. J. Nieto, "Biotechnological applications and potentialities of halophilic microorganisms," World Journal of Microbiology and Biotechnology, vol. 11, no. 1, pp. 85-94, 1995. 

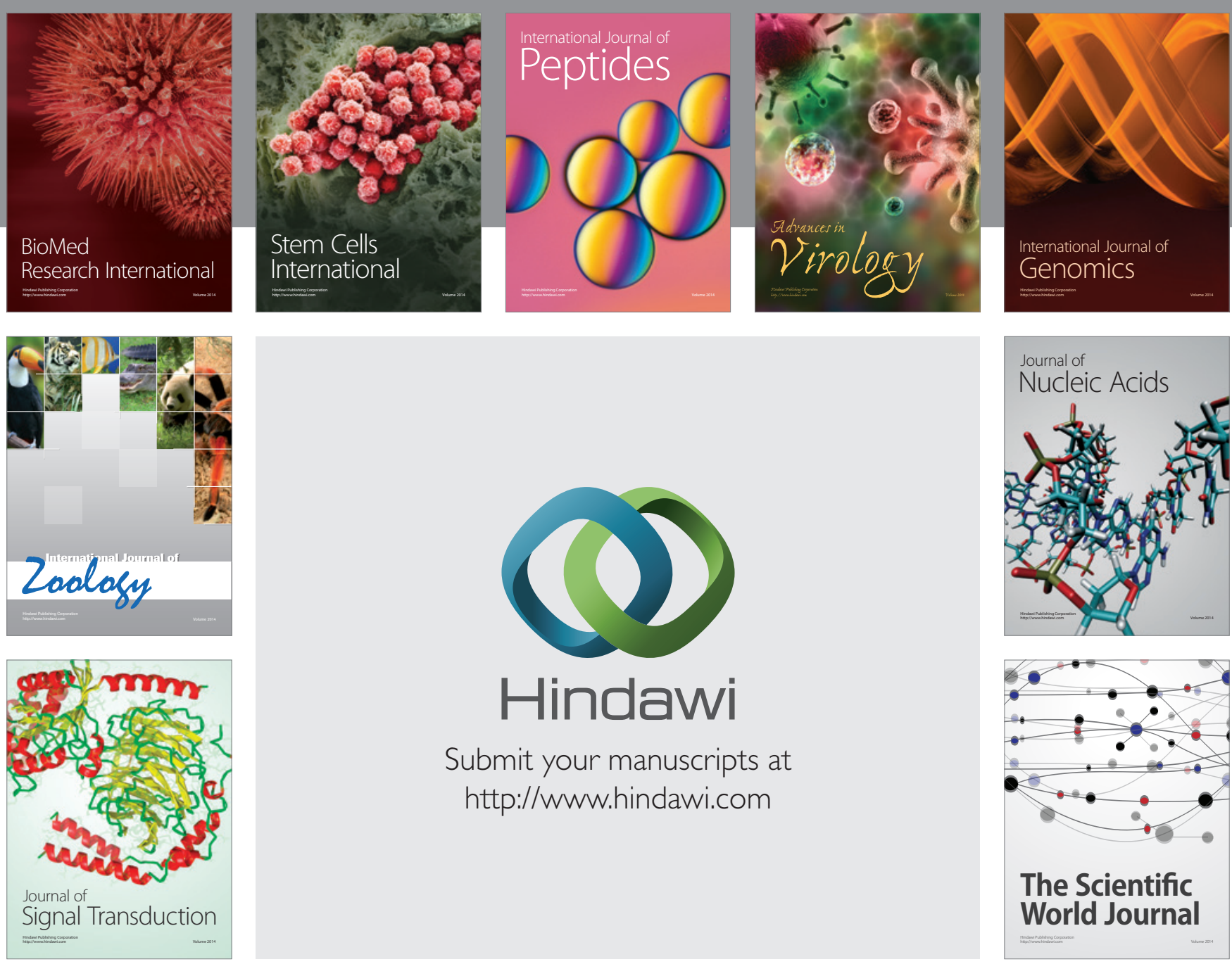

Submit your manuscripts at

http://www.hindawi.com
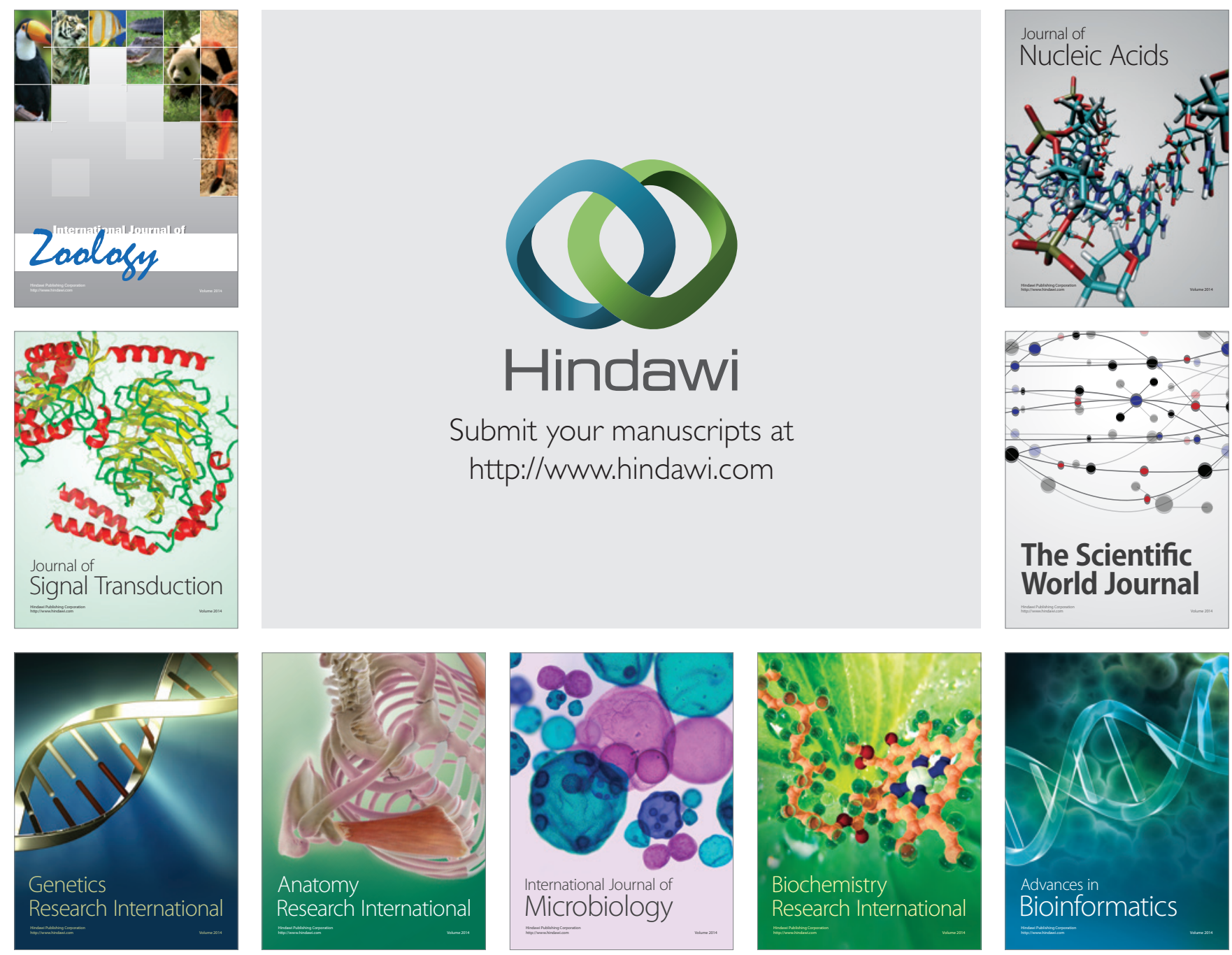

The Scientific World Journal
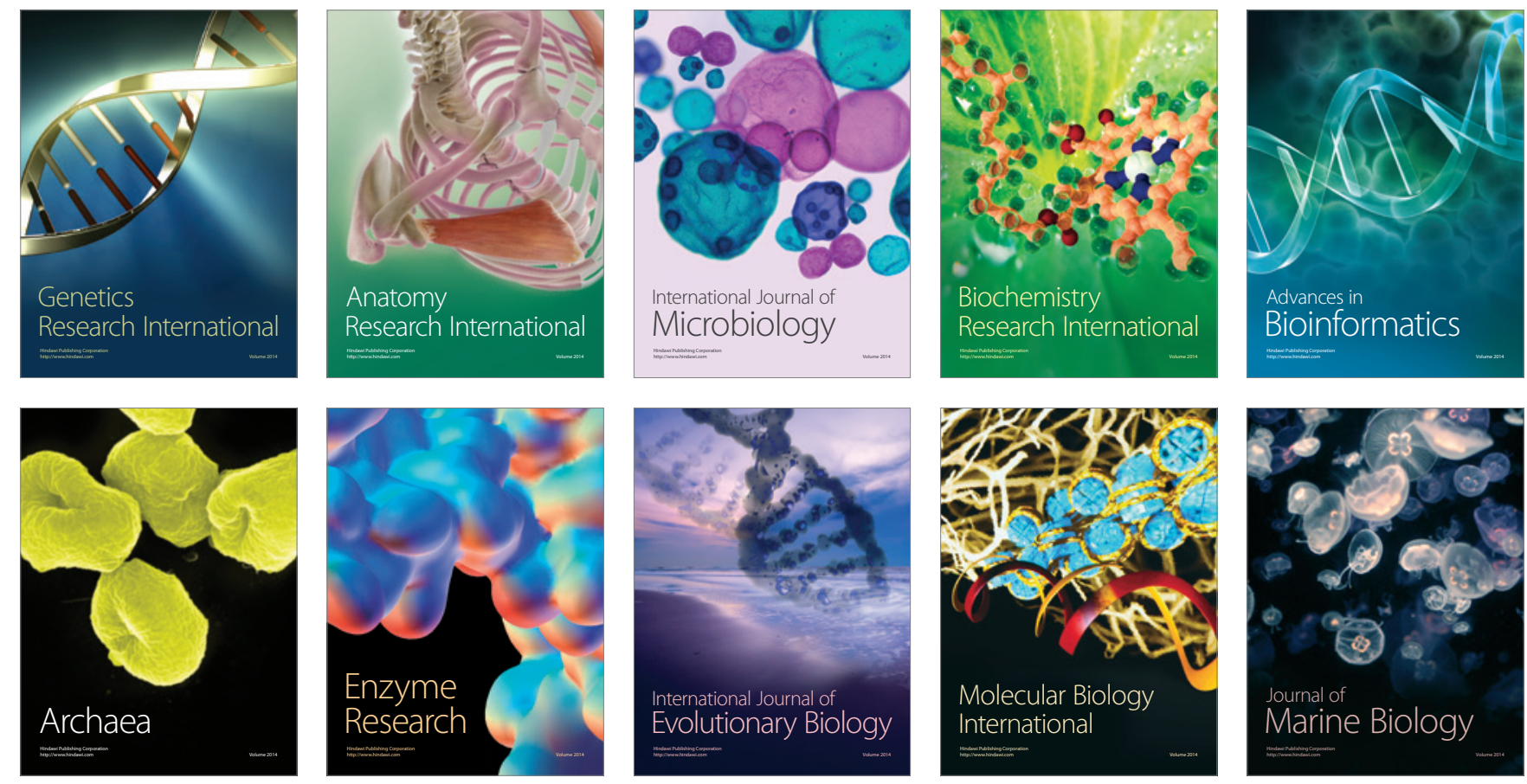